\title{
APPLICATION OF HALAL CERTIFICATION BY INDONESIAN ULEMA COUNCIL ON ELECTRONIC AND NON CONSUMPTION PRODUCTS: MASLAHAH PERSPECTIVE
}

\author{
Zarul Arifin* \\ Faculty of Sharia, Islamic Institute of Sultan Muhammad Syafiuddin Sambas, \\ Indonesia \\ Email: zarularifin89@gmail.com \\ Hatoli \\ Faculty of Sharia, Islamic Institute of Sultan Muhammad Syafiuddin Sambas, \\ Indonesia \\ Email: hatolipraktis@yahoo.co.id
}

* Corresponding author

DOI: 10.21154 /justicia.v18i1.2397

\begin{tabular}{l|l|l}
\hline Received: Nov 29, 2020 & Revised: Feb 3, 2021 & Approved: April 15, 2021 \\
\hline
\end{tabular}

Abstract: The background of this research is indications from those who criticize the granting of halal certification on electronic and non-consumption products. At the same time, the critics say that the granting of halal certification is only a religious capitalization, the mode of following the MUI trend, getting fees. Some say that this is the miss-perception. This research was conducted in August 2019. This study analyzes how MUI halal certification is in electronic and non-consumption products and how halal certification in electronic and non-consumption products is in perspective. This type of research is field research with an empirical sociological approach and descriptive qualitative research. Data collection techniques used are literature, interviews, and documentation based on secondary sources obtained from dictionaries, brochures, expert opinions, and religious leaders. Based on the study results, it is concluded that the application of MUI halal certification in electronic products is still voluntary, so there is no mandatory (obligation) from business actors to register their products in obtaining halal certification. The application of MUI halal certification in electronic and non-consumer products, firstly for refusingmudharat must take precedence over taking little benefit. Secondly, for companies or producers, applying for halal certification aims to provide a sense of security and comfort in the community and increase the added value of their products and finally, the existence of halal products even though they are non-consumption besides having benefits for people because they are more confident in the products used also giving benefit to the company and fulfilling the provisions in the Act.Theoretically, this research's benefits are expected to provide reading sources and guidelines for the development of science, especially in Islamic law related to halal certification by the Indonesian Ulema Council on electronic and non-consumer products. Practically, the results of this study are expected to provide clear information to the public regarding the application of halal certification by the Indonesian Ulema Council on electronic and non-consumption products. 
Zarul Arifin \& Hatoli, Aplication of Halal Certification by Indonesian Ulema Council ...

Penelitian ini dilatarbelakangi oleh adanya indikasi dari pihak yang mengkritisi pemberian sertifikasi halal pada produk elektronik dan non konsumsi, sedangkan yang mengkritik pemberian sertifikasi halal hanya sebagai kapitalisasi agama, modus mengikuti trend MUI, mendapat iuran dan ada yang bilang kaprah ini salah. Penelitian ini dilakukan pada bulan Agustus 2019. Penelitian ini bertujuan untuk menganalisis bagaimana sertifikasi halal MUI pada produk elektronik dan non konsumsi serta bagaimana penerapan sertifikasi halal pada produk elektronik dan non konsumsi. Jenis penelitian ini adalah penelitian lapangan dengan pendekatan sosiologis empiris, penelitian kualitatif deskriptif. Teknik pengumpulan data yang digunakan adalah studi pustaka, wawancara, dan dokumentasi berdasarkan sumber sekunder yang diperoleh dari kamus, brosur, pendapat ahli, dan pemuka agama. Berdasarkan hasil penelitian disimpulkan bahwa penerapan sertifikasi halal MUI pada produk elektronik masih bersifat sukarela, sehingga belum ada keharusan (kewajiban) dari pelaku usaha untuk mendaftarkan produknya untuk memperoleh sertifikasi halal. Penerapan sertifikasi halal MUI pada produk elektronik dan non-konsumen yang pertama menolak mudharat harus diutamakan daripada mengambil manfaat yang kecil. Kedua bagi perusahaan atau produsen, pengajuan sertifikasi halal bertujuan untuk memberikan rasa aman dan nyaman pada masyarakat serta meningkatkan nilai tambah produknya dan akhirnya keberadaan produk halal meskipun tidak dikonsumsi, selain bermanfaat bagi masyarakat. karena mereka lebih yakin produk yang digunakan juga menguntungkan perusahaan, serta memenuhi ketentuan di UU. Secara teoritis, manfaat penelitian ini diharapkan dapat memberikan sumber bacaan dan pedoman bagi pengembangan ilmu pengetahuan khususnya di bidang syariat Islam terkait penerapan sertifikasi halal oleh Majelis Ulama Indonesia pada produk elektronik dan non konsumen. Secara praktis, hasil penelitian ini diharapkan dapat memberikan informasi yang jelas kepada masyarakat terkait penerapan sertifikasi halal oleh Majelis Ulama Indonesia pada produk elektronik dan non konsumsi.

Keywords: MUI; Halal Label; Certification.

\section{INTRODUCTION}

Consuming halal products is a right of every individual as a citizen guaranteed by the 1945 Constitution. Through the Ministry of Religion, with Indonesia with the largest Muslim population globally, it is not surprising that the government encourages industry actors to provide halal products that are the basic needs of Muslims resulted from the flood of products from within and outside the country. ${ }^{1}$ If a product does not include a halal label, it may have a fatal impact on the individual and the company.Islamic Sharia pays much attention to determine whether food is halal, haram, or doubtful (syubhat). ${ }^{2}$ The requirement to include halal products in a product is stipulated in Law Number 33 of 2014 on Halal Product Guarantee (JPH). ${ }^{3}$ In the law on halal product guarantee, it is stated that

1 Dewi Kirana Windikusama., Pengaruh Kesadaran Halal Terhadap Sikap Dan Implikasinya Terhadap Minat Beli Ulang (Semarang: Universitas Diponegoro, 2015). 3

2 Muhtar Ali, "Konsep Makanan Halal Dalam Tinjauan Syariah dan Tanggung Jawab Produk Atas Produsen Industri Halal." 16,no. 02 (Desember 2016): 291.

3 “See Article 1 Paragraph (5) Law Number 33/2014 Concerning Guarantee of Halal Products.," n.d. 
halal products are products following Islamic law. In contrast,halal products' guarantees or coverage are legal provisions regarding the halal label of products marked with a halal certificate. ${ }^{4}$

The guaranteed halal label of a product is essentialin recognizing the rapid development of science and technology that impacted the birth of various ready-to-eat products with various ways of processing and utilizing production materials. Thus, nothing halal may be mixed with haramand becomes difficult to distinguish when it has become a final product. ${ }^{5}$ According to Islamic law, halal awareness is the level of knowledge possessed by Muslim consumers to seek and consume halal products. Islamic law teaches that a Muslim's consciousness is marked by knowledge of the process of slaughtering, packaging food, and food hygiene. ${ }^{6}$

The halal label is issued by the Halal Product Guarantee Agency (BPJPH) based on a written halal fatwa issued by the Indonesian Ulema Council (MUI). ${ }^{7}$ If previously halal certification was made through one door, namely LPPOM MUI, now the certification process is managed through BPJPH under the Ministry of Religion. Institutions can later carry out the product content processoutside the MUI, such as universities and foundations receiving MUI accreditation. However, the product must still get halal fatwa from MUI. This fatwa's determinationis carried out in a meeting attended by members of the MUI Fatwa Commission. ${ }^{8}$

The MUI fatwa conceptually determined always comes from the Shari'a (maqāsid syarī'ah) to provide sustainable maslahah (goodness) and eliminate mudharat. In other words, the consideration of the issue in the MUI fatwa is the initial purpose of the introduction and development of the Islamic economy itself, especially for products without halal certification. ${ }^{9}$

For example,related to this issue, moderate Islamic observer, Neng Dara Affiah, criticized halal certification for non-food and beverage products by naming it as religious capitalization, and this was a trend following the MUI because, in the case of halal labeling, MUI will get a fee. Also,in the matter of Islamic banking, MUI officials get a position. This had encouraged many parties' suspicion when the MUI issued its fatwa based on sharia and its halal label. ${ }^{10}$

4 Aminatuz Zahrah., "Halal Food Di Era Revolusi Industri 4.0; Prospek Dan Tantangan .," Indonesia Journal of Multidisciplinary Islamic Studies 3,no. 2 (Juli 2019) : 128.

5 Muhammad Djakfar., Hukum Bisnis Membangun Wacana Intergrasi Perundangan Nasional Dengan Syariah (Malang: UIN Maliki Press, 2013). 227

6 Eka Dyah Setyaningsih, "The Effect of Halal Certification and Halal Awareness Through Interest in Decisions on Buying Halal Food Products."," Journal Of Islamic Economics, Finance And Banking 3,no. 1 (Mei 2019): 65.

7 See Article 1 Paragraph (10) Law Number 33/2014 Concerning Guarantee Halal Producs,".

8 Makruf Amin, Fatwa Dalam Sistem Hukum Islam. (Jakarta: eISAS, 2008). 275

9 M. Atho Mudzhar, Esai-Esai Sejarah Sosial Hukum Islam (Yogyakarta: Pustaka Pelajar, 2014). 146

10 Neng Dara Affiah in the British Broadcasting Corporation (BBC) Indonesia, Written by Callistasia Wijaya (BBC Indonesia Journalist), as of 14 August 2019.,". 
Zarul Arifin \& Hatoli, Aplication of Halal Certification by Indonesian Ulema Council ...

Not only that, but criticism was also conveyed by the Special Staff of the Vice President for Economic and Financial Affairs, Wijayanto Samirin, that a refrigerator certified with the halal label is misguided. He referred to Article 1 paragraph (1) of Law Number 33 in 2014 on Guarantees of Halal Products related to "used goods," including clothes, shoes, bags containing animal elements such as fur, leather, and bones. Even the head of the Ministry of Religious Affairs BPJPH, Sukoso, said similar things. ${ }^{11}$ Halal certificate is an essential thing for Muslim consumers because it involves aspects of belief in religious matters. Every Muslim community's right to know that the products consumed are under Islamic law and teachings. ${ }^{12}$

Halal certification should be a priority for every producer in Indonesia, whether for consumption or non-consumption. Considering that Indonesia is the largest Muslim country globally, it is necessary to have excellent legal protection by applyinghalal certification. Besides, halal certification can be one of Indonesia's advantages to increase export products to countries with Muslim majority populations to protect the public interest. This was carried out beforeimplementing the Halal Product Guarantee Agency (BPJPH) on 17 October 2019. The Indonesian Ulema Council, the Supervisory Agency, Medicine and Food, the Ministry of Health, and several other relevant ministries/ agencies made the memorandum of understanding. In other words, the issuance of halal certification is now under the Ministry of Religion, so that the Indonesian Ulema Council no longer issues halal certification as in previous years. ${ }^{13} \mathrm{Halal}$ certification is a business ethic that producers should carry out as a guarantee of halal for consumers. Apart from being a guarantee of halal for consumers, the halal label provides economic benefits for producers. Firstly, it can increase consumer confidence because it is guaranteed with a halal license. Next, it has a USP (Unique Selling Point), Able to penetrate the global halal market, Increase the marketability of products in the market, andbe a cheap investment compared to the revenue growth achieved. ${ }^{14}$

The approach of this study is an empirical sociological approach. According to Ronny Hanitijo Soemitro, an empirical sociological approach is a literature approach guided by regulations, books, or legal literature and materials that have a relationship between problems and discussions in this writing and direct

11 Wijayanto Samirin and Sukoso in British Broadcasting Corporation (BBC) Indonesia, Written by Callistasia Wijaya (BBC Indonesia Journalist), as of 14 August 2019.,".

12 Yuyut Prayuti, "Muslim Food Consumer Protection Through The Regulation Of Halal Labels In Indonesia," Jurnal IUS Kajian Hukum Dan Keadilan 8, no. 1 (April 28, 2020): 17-25, https://doi. org/10.29303/ius.v8i1.716.

13 Muhammad Syarif Hidayatullah., "Sertifikasi Dan Labelisasi Halal Pada Makanan Perspektif Hukum Islam.," Yudisia Jurnal Pemikiran Dan Hukum Islam, 11,no. 2 (Desember 2020): 225.

14 Hayyun Durrotul Faridah, "Sejarah Sertifikasi Halal Di Indonesia Sejarah, Perkembangan, Dan Implementasi ..," Journal Of Halal Product and Research 2,no 2 (Desember 2019): 69. 
data collection on research objects related to halal certification. The method of the study uses qualitative research. Qualitative research is an approach or tracing to explore and understand themain symptom.

Based on the examples presented, it seems that fatwas often invite pros and cons, and almost always. Is it true that the perception that the issuance of halal labels by MUI only follows trends, the use of elite groups for projects, or their orientation due to financial factors? What about considering the MUI fatwas issues that form the basis for developing products with not halal to become halal certified? At this level, the authors are interested in researching and reviewing it with the title "Application of halal certification in electronic products and non-consumption through amaslahahperspective." The focus of the Problem; "What is the MUI halal certification system for electronic and non-consumption products?", How is the application of halal certification in electronic products and non-consumption of Maslahah perspective?

\section{HALAL CERTIFICATION}

\section{Definition of Halal Certification}

Halal certificate issued by the Central or Provincial MUI regarding the halal of food, beverage, medicines, and cosmetics products produced by a company after being examined and declared halal LPPOM-MUI. The authority issuing halal product certification is the Indonesian Ulema Council (MUI), technically handled by the Food, Drug and Cosmetics Assessment Institute (LPPOM). ${ }^{15}$

Whereas halal certification in the National legal system in Indonesia has a central position because halal certification is stipulated in Law Number 33 of 2014 on Halal Product Assurance, which in the legal system is part of the legal system, the legal substance ishaving a legal force and certainty law. Moreover, this is an effort to protect consumers according to Islamic law. ${ }^{16}$ To support the halal certification process, LPPOM MUI establishes requirements as a series of halal certification processes. Before conducting an audit of companies by registering halal certification with LPPOM MUI, the requirement is a Halal Assurance System (SJH).

2. The concept of maslahah in Islamic Legal Theory

a. Definition of Maslahah

According to the language, the word maslahah comes from Arabic and has been standardized into Indonesian to be the word maslahah, which means to bring

15 Mashudi, Kontruksi Hukum Dan Respons Masyarakat Terhadap Sertifikasi Produk Halal. (Yogyakarta: Pustaka Pelajar, 2015). 115

16 Panji Adam, “Kedudukan Sertifikasi Halal Dalam Sistem Hukum Nasional Sebagai Upaya Perlindungan Konsumen Dalam Hukum Islam," Amwalunavol 1, (Januari 2017): 161. 
good or bring benefit and resist damage. ${ }^{17}$ According to the original language, the word maslahah comes from the word salahu, yasluhu, salahan, صالحا, يصلح, صلح means something good, proper, and functional. ${ }^{18}$

Maslahah, etymologically, is a single word from al-masalih, which means the word wrong, which is "bring goodness" sometimes also used another term that is al-istislah which means "looking for a good" not infrequently the word maslahah or istislah is accompanied by the word al-mu fate which means "things which are suitable, appropriate and appropriate for their use." ${ }^{19}$ From some of these meanings, it can be understood that everything and anything containing benefits in it, both to obtain benefits, goodness, and to reject harm. Then, all of that is called maslahah. In terminology, maslahah can be interpreted as taking benefits and rejecting mudharat (danger) to maintain the aim of syara (Islamic law). ${ }^{20}$

\section{b. Maslahah According to Ulema}

Maslahah,according to the expert Ushul Ulema described by Imam al-Ghazali, maslahah in the initial sense is to draw benefit or reject madharat (something that causes harm).However, that is not what we want because the cause of achieving usefulness and denying harmis a goal or purpose of creatures, as for the goodness or benefit of creatures lies in the achievement of their goals. We mean by maslahah is to maintain or preserve the purpose of shara', as for shara' associated with the creatures there are five, namely the preservation of them (the creatures) of religion, their souls, their intellect, nasab or their descendants, and their possessions. Everything containing or includingthe maintenance of the five essential points is maslahah, and everything that denies the five essential points is mafsadah. In contrast, if it rejects it (something that denies five essential points), it is maslahah. ${ }^{21}$

Maslahah is everything to give rise to an action, in the form of good things, while in Sharia's terminology, there are various definitions. Mustafa Syalbi concludes in two senses. Maslahah is a result arising from an action, which is in the form of goodness or usefulness. Imam Ghazali defines maslahah as something that can bring benefits and overcome the damage. ${ }^{22}$

According to Asy-Syatibi, maslahah is any principle of sharia 'which is not accompanied by specific narrative evidence, but under the act of shari and it is meaning is taken from the arguments of sharia. According to Imam Malik,

17 Munawar Kholil, Kembali Kepada al Quran Dan as Sunnah. (Semarang: Bulan Bintang, 1955). 43

18 Muhammad Yunus, Kamus Arab Indonesia (Jakarta: Yayasan Penyelenggaraan Penerjemah dan penafsiran Al Quran, 1973). 219

19 H. M. Hasbi Umar, Nalar Figh Kontemporer Cet. I (Jakarta: Gaung Persada Press, 2007). 112

20 Harun, "Pemikiran Najmudin At-Thufi Tentang Konsep Maslahah Sebagai Teori Istinbath Hukum Islam," Jurnal Digital Ishraqi Volume 5 Nomor 1 Tahun 2019 (n.d.): 24

21 Moch Syarifuddin, "Maslahah Sebagai Alternatif Istinbath Hukum Dalam Ekonomi Syariah.," Jurnal Lentera Keagamaan, Kelilmuan, Dan Teknologi, Volume 17 Nomor 1 Tahun 2018 (n.d.): 49.

22 Jamal Makmur Asmani., Figh Sosial Kiai Sahal, Antara Konsep Dan Implementasi. (Jakarta: Khalista, 2009). 285 
maslahah is any benefit not based on a particular test that shows whether muktabar (recognized) or not its benefits. ${ }^{23}$

Thus, maslahah is a benefit without a basis as the proposition, and there is no basis as the proposition that justifies it. Therefore, if a case is found that the legal provisions do not exist and there is no criminal law that can be excluded from the Sharia determining the legal certainty of the case, then something is found following the Islamic law, in the sense of a legal provision based on maintenance of madharat or states that something is beneficial. A case like this is known as maslahah. ${ }^{24}$

\section{c. Attention Qur'an and Sunnah Against Maslahah}

Maslahah is the primary goal of a law (maqāsid syari'ah), ${ }^{25}$ or in other words, the substance of the maqāsid syarī'ah is a benefit. ${ }^{26}$ Islamic law is constantly faced with the challenges of change and development of society as well as stated by M. Atho Mudzhar that Islamic law must not be immune to change because the purpose of the law is to protect human interests on a universal scale, and scholars agree that Islamic law is suitable at all times and the place. Thus, the Qur'an has laid down the basic foundations and general principles of the subject of Islamic law, which are among the principles of the maslahah. Furthermore, Islamic law theorists conclude that maslahah is the core objective/principle of establishing Islamic law. ${ }^{27}$

1) The First Proposal

Remember when your Lord said to the Angels: "Verily, I want to make a caliph on earth."(Q.S Al-Baqarah: 2/30)

In addition to affirming Allah's plan to create humanity on the face of the earth which he disguised to the angels, this verse also signifies the purpose of that, namely as the caliph. Thus, the caliph is a problem in order to achieve the secret of the creation of humanity.

2) Second Theorem

And I did not create jinn and men but that they might serve me.

(Q.S Al-Dzariyyat: 51/56).

This verse confirms that creating humans and jinn is to worship, serve and worship God. Thus, devotion and worship of Allah is the problem desired by Allah behind the secret why humans and jinns were created.

\footnotetext{
Rahmat Syafi'i, Ilmu Ushul Figh. (Bandung: Cv Pustaka Setia, 2010). 121-122

Amir Syarifuddin, Ushul Fiqh Jilid 2. (Jakarta: Kencana Pranada Grup, 2009). 346

Junaidi Lubis, Islam Dinamis (Jakarta: PT Dian Rakyat, 2010). 120

Totok Jumantoro, Kamus Ilmu Ushul Figh (Jakarta: Amzah, 2009). 120

27 Asmawi, Aplikasi Kaidah Maslahah Dalam Delik Ta'zir, Dalam Laporan Penelitian Individu (Jakarta: Lemlit UIN Syarif Hidayatullah Jakarta, 2005). 25
} 
Zarul Arifin \& Hatoli, Aplication of Halal Certification by Indonesian Ulema Council ...

3) Third Theorem

On this day, I have perfected for you your religion, and I have supplied you with my favors, and I have accepted that Islam is a religion for you (QS AlMāidah: 5/3).

As the proof/source of the Islamic law functioningas a bayan (tabyin) against the Qur'an, the messages conveyed by the Sunnah/ Hadith are always in line and relevant to the Qur'an. If the messages of the Qur'an about law are loaded with the principle of the maslahah, so that it is the case with the Sunnah/ Hadith where the principle of the maslahah often accompanies the messages about the law. This can be seen from the following hadith: Abu Hurairah radhiyallahu 'anhu said the Prophet Muhammad said, "Among the signs of the goodness of one's Islam: if he leaves things that are not beneficial to him." (at-Tirmidhi no. 2318). ${ }^{28}$

\section{d. Maslahah Categorization}

Maslahah can be categorized based on the quality and importance of the benefit, the content of the benefit, the change or not of the benefit, and the existence of the maslahah. The more detailed explanation is as follows:

1) Maslahah based on the terms of changing maslahat

According to Mustafa asy-Syalabi (professor of fiqh at al-Azhar University, Cairo), there are two forms of benefit based on the terms of benefit change. First, al-maslahah as-sabitah, that is, permanent benefit, does not change until the end of time. For example, various religious obligations such as prayer, fasting, almsgiving, and pilgrimage. Second, al-maslahah almutagayyirah, which is the benefit that changes according to changes in place, time, and subject of this kind of benefits law related to issues of muamalah and customs, as in the problem of food varies among regions the necessity of this division, according to Mustafa ash-Shalabi, is intended to provide limits on the benefits that can change and which do not change. ${ }^{29}$

2) Maslahah is based on the existence of maslahah, according to syara'.

This benefit is,according to Mustafa ash-Shalabi divided into three types, namely:

a) Maslahah mu'tabarah

Maslahah mu'tabarah is a maslahah expressly recognized by the Sharia and has stipulated legal provisions to realize it. ${ }^{30}$ As said by Muhammad al-Said Abi Abd Rabuh, maslahah mu'tabarah is

28 Imam An Nawawi, Syarh Arbain An Nawawiyah. (Jakarta: Darul Haq, 2006). 24

29 Abdul Azis Dahlan, Ensikplopedi Hukum Islam (Jakarta: Ichtiar Baru Van Hoeve, 1999). 1145

30 Efendi Satria, Ushul Figh (Jakarta: Pranada Media, 2005). 149 
a benefit recognized by sharia, and there has a clear proposition to preserve and protect it.

b) Maslahah Mulgah

Maslahah mulghah is also a maslahah that the Sharia does not recognize through plain texts. In other words, the benefit is rejected because there is an argument showinga contrary to the provisions of a clear argument. For example, isan equal distribution between men and women in the distribution of heirlooms. ${ }^{31}$

c) Maslahah Mursalah

The problem of the problem is referred to in this discussion. The meaning of which is like the definition mentioned above. This problem exists in the problems of muamalah in the Qur' an and asSunnah to be able to make an analogy, for example, traffic rules with all signs -the ambulance, such a regulation do not exist in a unique proposition that governs it, either in the Qur'an.

\section{e. Maslahah based on quality and benefits aspects}

The Jurisprudence experts suggest several divisions of benefits based on the quality and importance of benefit, and they divide them into three forms as follows:

1) Al-Maslahah al-Dharuriyyah

Benefit related to the basic needs of humanity in the world and the hereafter or in other words, Al-Maslahah al-Dharuriyyah (immediate needs) is a basic need that involves realizing and protecting the existence of the five points, namely preserving religion, preserving souls, protecting the mind, preserving offspring, and preserving property according to the experts on fiqh. These five benefits are called al-masalih al-khamsah. If this benefit is lost, then human life will be destroyed, and humankind will not survive both in the world and in the hereafter. According to al-Syathibiy, the importance of the five things is that religion and the world can balance. If those are maintained, they will be able to provide happiness for the community and individuals.

2) Al-Maslahah al-Hajiyyah

The benefit needed in completing the primary benefit in the form of relief to maintain basic human needs, in other words, the needs of alHajiyyah (secondary needs) is something needed for human life but does not reach the level of dharury if these are not fulfilled, these will

$31 \quad$ Abdul Karim Zaydan, Ushul Figh (Surabaya: Media, 2009). 187 
Zarul Arifin \& Hatoli, Aplication of Halal Certification by Indonesian Ulema Council ...

not negate or destroy life itself, but its existence is needed to provide convenience in life. ${ }^{32}$

3) Al-Maslahah al-Tahsiniyyah

The Benefit is complementary in the form of freedom that can complement the previous benefits. In other words, it is complementary to the needs of life and further enhances the welfare of human life. If the benefit of Tahsiniyyah is not fulfilled, then the benefit of human life will feel less beautiful and less enjoyable, even if it does not cause welfare. ${ }^{33}$ Destitutionand destruction of life. Its existence is desired for moral glory and good social order.

\section{f. Prosperity Maslahah}

A difference will end in grace. Presumably, this is used by the fuqaha when looking at istihsàn as one of the propositions in establishing sharialaw. Thus, various opinions emerge. The groups of Shafi'i, Zahiriyah, Sy'ah, and Mu'tazilah scholars do not accept istihsàn as hujjah, especially istihsànbi al-'urf for Imam al Gazallì. They give a variety of reasons. The point is that with Istihsàn, a person (mujtahid) is worried about being trapped in setting laws based on reason and lust, and this has never been applied by the Messenger of Allah nor a transparent and accountable benchmark about it.

In contrast to al-Shatibi, he states that istihsàn is not solely based on logic and lust but a stronger proposition (in its benefit content) and through the induction of some texts, not partially. Therefore, al-Sahibí is classified as a scholar who receives that Istihsàn can be made hujjah. In line with al-Shafi'i are Hanafiyah scholars, Màlikiyyah,and some Hanàbilah scholars. Of the various opinions that existed, they have a valid and quite strongargument.Although there are differences, what is used as the base of the problem is the fear of a human being trapped in their lust when taking maslahat (istihsàn) as hujjah. As a result, engaging in istihsàn is permissible as long as it does not just take something good because of impulse for better reasons without seeing other arguments that should be used as material for comparison and consideration. ${ }^{34}$

\section{g. Criteria for Maslahah According to MUI}

The criteria according to the MUI can be seen as follows:

1) Maslahat/ benefit according to Islamic law is the attainment of the goals of the sharia (maqashid al-shari'ah), which is realized in the form

Amir Syarifuddin, Ushul Figh (Jakarta: Logos Wacana Ilmu, 1999). 213

Hamka Haq, Filsafat Ushul Figh (Makassar: Yayasan Al Ahkam, 1998). 76

34 Moh. Mahrus, "Al Maslahah Menurut Abu Hanifah, Karakteristik, Kehujjahan, Dan Signifikasinya Dalm Berijtihad.," Jurnal Hukum Islam Vol 14, 1 Tahun (2015): 39. 
of the maintenance of five primary needs (al-dhariyyat al-khams), namely religion, reason, soul, wealth, and descent.

2) Benefits justified by sharia are benefits that are not contrary to the text. Therefore, benefits should not conflict with the text.

3) According to the Sharia, those who have the right to determine the benefit of something are institutions having competence in Sharia and are carried out through ijtihad jama'i. ${ }^{35}$

\section{MUI HALAL CERTIFICATION ON ELECTRONIC AND NON- CONSUMPTION PRODUCTS}

Consumers in Indonesia have started to pay attention to halal labels. This is proven halal label affects the sale of food products. The issue of pork fat in 1988 caused a drop in sales turnover of some food products. The issue of mixing beef with wild boar meat, causing a drop in sales turnover of meat and processed products. The issue of rats, fish, and formalin chicken meatballs and many other cases shows Indonesian people's awarenessof good halal food. ${ }^{36}$

Government regulations related to product standards, especially halal food in Indonesia, are not entirely new. Indonesia has already had halal certification guidelines issued by the Indonesian Ulema Council. Namely, the Requirements of Halal Certification HAS 23000. ${ }^{37}$ Besides, various elements ensure the halal value chain of food production. Applicability of Law No. 33 of 2014 on Halal Product Guarantee aims to provide certainty to the public regarding halal products, whereas non-halal products will not have an affirmation of illicit product types. Non-halal products will only include images of the contents contained therein, such as the presence of animal heads, while alcoholic beverages will be given the symbol of a bottle. ${ }^{38}$

Halal certification by MUI is a process for obtaining halal certificates through several stages to prove that materials, production processes, and SJH meet LPPOM MUI standards. ${ }^{39}$ Previously, halal certification was only legalized through one door, namely LPPOM MUI.Nevertheless, nowadays, the certification process is managed through BPJPH under the Ministry of Religion. ${ }^{40}$ Institutions can later carry out the product content processoutside the MUI, such as universities and

35 Fatwa of Indonesia Ulema Council Number 6/MUNAS/VII/MUI/10/2005, Concerning Maslahah Criteria, 485.," .

36 Ichwan Sam, Ijma Ulama Keputusan Ijtima Ulama Komisi Fatwa Se Indonesia Tahun 2009. (Jakarta: Majelis Ulama Indonesia, 2009). 95

37 Wahyu Suseno, "Tingkat Penggunaan Bahan Tersertifikasi Halal Berdasarkan Usulan Bidang Audit Kepala Tim Komisi Fatwa Provinsi Banten.," Indonesian Journal Of Halal Vol. 8. No. 1 Tahun 2018 : 44.

38 Siti Muslimah, "Label Halal Pada Produk Pangan Kemasan Dalam Perspektif Perlindungan Konsumen Muslim.," Jurnal Yustisia Vol. 1 No. 2 Tahun 2012 : 90.

39 Mohamad Nadtratuzzaman Hosen, Panduan Umum Sistem Jaminan Halal. (Jakarta: LPPOM MUI, 2008). 8

40 See, Article 5 Paragraph (3) Law Number 33/2014 Concerning Guarantee Halal Producs.,. 
Zarul Arifin \& Hatoli, Aplication of Halal Certification by Indonesian Ulema Council ...

foundations that have received MUI accreditation. However, the product must still get halal fatwa from MUI.

The fatwa's determination on halal products' issue is carried out by the Indonesian Ulema Council Fatwa Commission. The fatwa's determination was carried out in a meeting attended by members of the MUI Fatwa Commission. To hold a fatwa determination meeting is based on:

a. Requests or questions from the community that the MUI Leadership Council considers necessary to discuss and give its fatwa.

b. Requests or questions from the government, social institutions/ organizations, or MUI itself.

c. Development and discovery of religious problems that arise due to society's changes and science and technology progress.

During the meeting process, the fatwa commission's secretary and deputy secretary records the commission members' suggestions and opinions to make the meeting minutes and the fatwa commission's decision materials. In some instances, the meeting can bring experts related to the problem being discussed.

After an in-depth and comprehensive discussion and attention to the opinions and views developed at the meeting, the fatwa was established. Fatwas determined by the fatwa commission through a fatwa commission meeting are immediately reported to the MUI Leadership Council to be announced to the public and the parties concerned.

Halal certification on electronic and non-consumption products is still only an appeal for business actors to pay attention to the materials used to produce them. Given that Muslims are the largest consumers in Indonesia, it is necessary to provide legal protection for consumers to use electronic and non-consumption products without worrying about using them from non-halal materials included in. Until now, quite a lot of electronic and non-consumer products have received halal certification.

\section{MUI HALAL CERTIFICATION ON ELECTRONIC AND NON- CONSUMPTION PRODUCTS THROUGH MASLAHAH PERSPECTIVE}

The circulation of electronic product advertisements in the form of halal refrigerators certified from the MUI with the number 00170087970318 in 2018 and several other non-consumption products make people wonder about the intent and purpose. A moderate Islamic observer, Neng Dara Affiah, criticized halal certification for non-food and beverage products, considering that these items should not be eaten. Even labeling as such could create community separation, especially between Muslims and non-Muslims. ${ }^{41}$

41 "Neng Dara Affiah in the British Broadcasting Corporation (BBC) Indonesia, Written by Callistasia Wijaya (BBC Indonesia Journalist), as of 14 August 2019." 
Sumunar Jati (Deputy Director of LPPOM MUI) said no provisions were requiring electronic goods to obtain halal certification. However, LPPOM MUI cannot refuse a certification request following the fatwa determination procedure. For companies or manufacturers, applying for halal certification aims to provide a sense of security and comfort in the community and increase their added value. In other words, halal products, even though they are non-consumption, besides giving benefit to the community because they are more confident in the products used, will also benefit the company and fulfill the Act's provisions.

Confidence in doing an action is in line with the rules;

"Faith cannot be dispelled with doubt."42

In the writer's opinion, this rule is very rational because halal certification is given to a product both consumption and non-consumption, that is, confidence about the product used. This rule leads us to the concept of ease in removing the difficulties that sometimes afflict us by building legal certainty by rejecting doubts. As we know, the result of doubt is burden and difficulty. Then we are instructed to know the law correctly and indeed so that it feels easy and light in carrying out Allah commands, including that it is a matter of something that is used or eaten. The concept is halālan tayyiban (halal again suitable), a healthy and safe product that certainly brings all problems.

Developing the halal industry is good, but it does not burden the entrepreneurs and become an obstacle for them to invest. It would be nice if each company only provided information related to what is contained in the product and the expiry date. Because labeling like this is sometimes used by groups of people, especially elites, for specific projects, whereas the cost of halal certification can reach Rp. 5 million for one product and must be renewed every two years. This impressed the MUI's mode of giving halal labels. However, with financial orientation and MUI, people also got available positions and seemed to find a way and force themselves to confirm what was haramto be halal. It should be noted that MUI will not issue a fatwa if there are no requests or questions from the public, whether itis from individuals, companies, legal entities, or financial institutions that are not operationalyet.

When there are questions or legal requests from the public about the halal label, a secretariat led by a secretary no later than one working day will submit the question to the chairman, MUI will conduct an in-depth study based on the nash, the events of the time of the Prophet, friends, or opinions of the previous scholars. After an in-depth study and found that this is not contrary to Islamic law and in line with the maqāsid al-Syariah (maslahat), the MUI fatwa was issued.

42 A. Muin dkk, Ushul Figh II (Jakarta: Departemen Agama, 1986). 195 
Zarul Arifin \& Hatoli, Aplication of Halal Certification by Indonesian Ulema Council ...

The Indonesian Ulema Council is a gathering place for ulemas who have the authority to perform jama' $i$ (collective) ijtihad and provide answers in responding to contemporary problems without prejudice to existing scholars' nash and opinions. Because if the ulama let the ordinary people look for their answers, it is hazardous to the people's religious life. Thus, the scholars are obliged to do ijtihad or istinbāt law to encourage people to have a properunderstanding. Refusing mudharat should take precedence over overtaking a small benefit. As the following jurisprudence;

Translation: "Refusing mudharat (danger) takes precedence over taking advantage."

Therefore, allowing ordinary people to search for answers and just guessing the halal label is very dangerous to people's religious life.

Many factors influence the halt of a product. Among them are animals slaughtered, slaughtering procedures, and contacting meat with other forbiddenobjects. Therefore, the halal label of a product is not limited to consumption but includes a comprehensive aspect, which is to use or use. Likewise, electronic products, such as refrigerators, as in direct contact with food products and as a place to store food to be consumed must be believed to its holiness. These ingredients should not be mixed with unclean materials, which will affect the halal nature of food products stored in them. Logically,MUI does provide not only halal certification on consumer products but also non-consumption.

From the assessment and audit process carried out by LPPOM MUI on the refrigerator product, some components are made from a mixture of materials usingfatty acid derivatives elements. Moreover, the research was conducted by LPPOM MUI. The fatty acid element is a crucial ingredient considered from the halal side because fatty acids usually come from animal ingredients. If it is animalbased, it must be ensured that the material is not from pig breeds, prohibited material in Islam. As a result, the product is not problematic in sharia principles, so that the MUI Fatwa Commission also established it as a halal and holy product. Thus, in the category of electronic products, especially refrigerators, the product is the first to receive halal fatwa by the MUI Fatwa Commission after a request.

Thus, in my opinion, the fatwa issued by the Indonesian Ulema Council on the halal status of a product is not looking for excuses so that the illegitimate one becomes halal or force themselves to confirm any conventional instruments to become sharia, nor are they ordered from certain parties for the shake of the business running smoothly, especially if the fatwa issued is alleged solely for commercial or popularity purposes. The fatwa issued by the MUI is solely to answer the challenges of the times, particularly the regulation of the Islamic economic system in Indonesia for the benefit of the people. 
If only the MUI wanted it to be commercial, it would have been easy. All that was left was for the fatwa to be issued even if no party submitted a fatwa request, provided they were willing to pay the fatwa. However, the reality is not like that. MUI is waiting (passive) and will only issue a fatwa if some people or institutions apply for a fatwa, then review it, and if it is justified, a fatwa will be issued.

\section{CONCLUSIONS}

After a study, analysis, and discussion in the previous chapter on applying halal certification to electronic and non-consumption products, the perspective of the maslahah was formulated and following the research objectives. It can be concluded as follows, MUI halal certification on electronic and non-consumption products is still voluntary, so there is no mandatory requirement from business actors to register their products to obtain halal certification. Application of halal certification on non-consumption electronic products in perspective refusing mudharat should take precedence over overtaking a small benefit. For companies or manufacturers, applying for halal certification aims to provide a sense of security and comfort in the community and increase their added value. The existence of halal products, although non-consumption, besides having benefits for the community because it is more confident with the products used, also provides benefits for the company, as well as meeting the provisions in the Act.

\section{REFERENCES}

A. Muin dkk. Ushul Figh II. Jakarta: Departemen Agama, 1986.

Abdul Azis Dahlan. Ensikplopedi Hukum Islam. Jakarta: Ichtiar Baru Van Hoeve, 1999.

Abdul Karim Zaydan. Ushul Fiqh. Surabaya: Media, 2009.

Aminatuz Zahrah. "Halal Food Di Era Revolusi Industri 4.0; Prospek Dan Tantangan." Indonesia Journal of Multidisciplinary Islamic Studies Vol. 3 No. 2 Juli 2019 (n.d.): 128.

Amir Syarifuddin. Ushul Figh. Jakarta: Logos Wacana Ilmu, 1999.

- - - . Ushul Figh Jilid 2. Jakarta: Kencana Pranada Grup, 2009.

Asmawi. Aplikasi Kaidah Maslahah Dalam Delik Ta'zir, Dalam Laporan Penelitian Individu. Jakarta: Lemlit UIN Syarif Hidayatullah Jakarta, 2005.

Dewi Kirana Windikusama. Pengaruh Kesadaran Halal Terhadap Sikap Dan Implikasinya Terhadap Minat Beli Ulang. Semarang: Universitas Diponegoro, 2015.

Efendi Satria. Ushul Figh. Jakarta: Pranada Media, 2005. 
Zarul Arifin \& Hatoli, Aplication of Halal Certification by Indonesian Ulema Council ...

Eka Dyah Setyaningsih. "The Effect of Halal Certification and Halal Awareness Through Interest in Decisions on Buying Halal Food Products."." Journal Of Islamic Economics, Finance And Banking Vol. 3 No. 1 Mei 2019 (n.d.): 65.

"Fatwa Majelis Ulama Indonesia Nomor 6/MUNAS/VII/MUI/10/2005, Tentang Kriteria Maslahah, 485.," n.d.

H. M. Hasbi Umar. Nalar Figh Kontemporer Cet. I. Jakarta: Gaung Persada Press, 2007.

Hamka Haq. Filsafat Ushul Figh. Makassar: Yayasan Al Ahkam, 1998.

Harun. "Pemikiran Najmudin At-Thufi Tentang Konsep Maslahah Sebagai Teori Istinbath Hukum Islam." Jurnal Digital Ishraqi, Vol 5, 1 (2019).

Hayyun Durrotul Faridah. "Sejarah Sertifikasi Halal Di Indonesia Sejarah, Perkembangan, Dan Implementasi." Journal of Halal Product and Research, Vol 2, 2 (2019).

Ichwan Sam. Ijma Ulama Keputusan Ijtima Ulama Komisi Fatwa Se Indonesia Tahun 2009. Jakarta: Majelis Ulama Indonesia, 2009.

Imam An Nawawi. Syarh Arbain An Nawawiyah. Jakarta: Darul Haq, 2006.

Jamal Makmur Asmani. Figh Sosial Kiai Sahal, Antara Konsep Dan Implementasi. Jakarta: Khalista, 2009.

Junaidi Lubis. Islam Dinamis. Jakarta: PT Dian Rakyat, 2010.

M. Atho Mudzhar. Esai-Esai Sejarah Sosial Hukum Islam. Yogyakarta: Pustaka Pelajar, 2014.

Makruf Amin. Fatwa Dalam Sistem Hukum Islam. Jakarta: eISAS, 2008.

Mashudi. Kontruksi Hukum Dan Respons Masyarakat Terhadap Sertifikasi Produk Halal. Yogyakarta: Pustaka Pelajar, 2015.

Moch Syarifuddin. "Maslahah Sebagai Alternatif Istinbath Hukum Dalam Ekonomi Syariah." Jurnal Lentera Keagamaan, Kelilmuan, Dan Teknologi, Vol 17, 1 (2018).

Moh. Mahrus. “Al Maslahah Menurut Abu Hanifah, Karakteristik, Kehujjahan, Dan Signifikasinya Dalm Berijtihad." Jurnal Hukum Islam, Vol 14, 1 (2015).

Mohamad Nadtratuzzaman Hosen. Panduan Umum Sistem Jaminan Halal. Jakarta: LPPOM MUI, 2008.

Muhammad Syarif Hidayatullah. "Sertifikasi Dan Labelisasi Halal Pada Makanan Perspektif Hukum Islam." Yudisia Jurnal Pemikiran Dan Hukum Islam, Vol 11, 2 (2020).

Muhammad Yunus. Kamus Arab Indonesia. Jakarta: Yayasan Penyelenggaraan Penerjemah dan penafsiran Al Quran, 1973.

Muhtar Ali. “Konsep Makanan Halal Dalam Tinjauan Syariah dan Tanggung Jawab Produk Atas Produsen Industri Halal." Vol 16, 02 (Desember 2016). 
Munawar Kholil. Kembali Kepada al Quran Dan as Sunnah. Semarang: Bulan Bintang, 1955.

"Neng Dara Affiah in the British Broadcasting Corporation (BBC) Indonesia, Written by Callistasia Wijaya (BBC Indonesia Journalist), as of 14 August 2019.," n.d.

Panji Adam. "Kedudukan Sertifikasi Halal Dalam Sistem Hukum Nasional Sebagai Upaya Perlindungan Konsumen Dalam Hukum Islam." Amwaluna, Vol 1, (Januari 2017)

Prayuti, Yuyut. "Muslim Food Consumer Protection Through The Regulation Of Halal Labels In Indonesia." Jurnal IUS Kajian Hukum Dan Keadilan 8, no. 1 (April 28, 2020): 17-25. https:// doi.org/10.29303/ius.v8i1.716.

Rahmat Syafi' i. Ilmu Ushul Figh. Bandung: Cv Pustaka Setia, 2010.

Siti Muslimah. "Label Halal Pada Produk Pangan Kemasan Dalam Perspektif Perlindungan Konsumen Muslim." Jurnal Yustisia Vol. 1 No. 2 Tahun 2012 (n.d.): 90.

Syafrida. "Sertifikat Halal Pada Produk Makanan Dan Minuman Memberi Perlindungan Dan Kepastian Hukum Hak-Hak Konsumen Muslim." Jurnal Hukum, Vol.7, 2 (2016).

Totok Jumantoro. Kamus Ilmu Ushul Fiqh. Jakarta: Amzah, 2009.

Wahyu Suseno. “Tingkat Penggunaan Bahan Tersertifikasi Halal Berdasarkan Usulan Bidang Audit Kepala Tim Komisi Fatwa Provinsi Banten." Indonesian Journal Of Halal Vol. 8. No. 1 Tahun 2018 (n.d.): 44.

“Wijayanto Samirin and Sukoso in British Broadcasting Corporation (BBC) Indonesia, Written by Callistasia Wijaya (BBC Indonesia Journalist), as of 14 August 2019.," n.d.

Zulham. Peran Negara Dalam Perlindungan Konsumen Muslim Terhadap Produk Halal. Jakarta: Kencana, n.d.

Law Number 33/2014 Concerning Guarantee of Halal Products

Fatwa of Indonesia Ulema Council Number 6/MUNAS/VII/MUI/10/2005

Concerning Maslahah Criteria 